\title{
Desert Cottontail Use of Natural and Modified Pinyon-Juniper Woodland ${ }^{1,2}$
}

\author{
JOHN N. KUNDAELI AND HUDSON G. REYNOLDS
}

Game Management Officer, College of African Wildlife, Moshi, Tanzania; and Principal Wildlife Biologist, Rocky Mountain Forest and Range Experiment Station, Forest Service, U.S. Department of Agriculture, Tempe, Arizona.

\section{Highlight}

Pinyon-juniper woodland, a habitat for desert cottontails throughout much of the West, is often cleared to improve grazing conditions for livestock. In southern New Mexico, habitat conditions for cottontails can be maintained or enhanced during clearing operations by preserving some combination of 70-90 down, dead trees and living shrubs per acre.

Desert cottontails (Sylvilagus auduboni Baird) are distributed widely throughout the western United States. These animals provide substantial recreational hunting. For example, about 29,000 hunters harvest over 185,000 cottontails annually in Arizona (Smith, 1962) while expending about $\$ 640,000$ (Davis, 1962). Maintenance of cottontail rabbit production to satisfy recreationists depends upon proper habitat management.

The range of cottontails includes 60 million acres of pinyon-juniper woodland in the Rocky Mountain and Intermountain Regions (Forest Service, 1958). This woodland, among other values, provides important forage for livestock. Many public and private land managers continue to clear areas of pinyonjuniper to improve forage production for livestock. This paper reports the effect of pinyon-juniper

\footnotetext{
${ }^{1}$ Received May 21, 1971.

${ }^{2}$ Results reported are based on Mr. Kundaeli's MS thesis to Colorado State University.
}

clearing upon the desert cottontail in southern New Mexico. Recommendations are given for coordinating clearing activities with the habitat needs of cottontails.

\section{Study Area and Methods}

This study was conducted on 13,000 acres of the Ft. Bayard Experimental Forest, about 10 miles east of Silver City, New Mexico. The area includes only elevations of 6,000 to $7,000 \mathrm{ft}$ in the pinyonjuniper. Rainfall averages about 16 inches. Considerable diversity of soils and topography provide a complex environment for plant growth. Percent density composition of trees is: pinyon (Pinus edulis Engelm.), 40; alligator juniper (Juniperus deppeana Steud.), 24; gray oak (Quercus grisea Liebm.), 24; Utah juniper (J. osteosperma (Torr.) Little), 10; other trees (15), 2. Similarly, shrub composition is: hairy mountainmahogany (Cercocarpus breviflorus A. Gray), 47; gray oak (less than $6 \mathrm{ft}$ tall), 20; Wright silktassel (Garrya wrightii Torr.), 18; skunkbush (Rhus trilobata Nutt.), 10; other shrubs (25), 5. Tree density varies from none on $7 \%$ of the area to sites with more than 250 plants/acre. Some areas support an equal density of shrubs, although $17 \%$ of the area is without shrubs.

Perennial grass production averages about $300 \mathrm{lb}$./acre. The dominant species-blue grama (Bouteloua gracilis (H.B.K.) Lag.) and sideoats grama (B. curtipendula (Michx.) Torr.)-contribute about two-thirds of the total. Over 30 species of perennial grasses make up the remainder of the production.

Forb production is about half that of perennial grasses. No forb species dominate the composition; of the more than 50 species involved, most abundant genera include: vetch (Vicia spp.), globemallow (Sphaeralcea spp.) goosefoot (Chenopodium spp.), and buckwheat (Eriogonum spp.).

In 1963, permanent pellet sampling stations were located at mechanically spaced intervals on the entire experimental area at an intensity of 25 per section (approximately 450 plots). In 1965 sampling intensity was increased to 225 stations per section on the southern one-third of the area.

Pellet plots at each sample station consisted of four belts laid out in cardinal directions. Each belt contained $1 / 400$ acre ( 3 by 36.3 feet). Presence or absence of accumulated cottontail rabbit pellets was noted annually on each sampling belt.

Trees and shrubs were counted around the center of each sample station on a $1 / 10$-acre plot (37.2-foot radius).

Herbaceous vegetation was estimated periodically by species on belts 1 by 24 feet in size superimposed over the pellet plots. Estimates of herbage were corrected to actual weight by double sampling (Wilm et al., 1944). Vegetation samples were dried so that production could be expressed as pounds of air-dry material per acre.

Pinyon-juniper was removed in various amounts and by several methods on the southern one-third of the experimental area in 1965 . The experimental design consisted 
Table 1. Occurrence $(\%)$ of desert cottontail pellets in relation to tree density (no./acre), shrub abundance (no./acre), and herbaceous vegetation production (lb./acre) on Ft. Bayard in 1966.

\begin{tabular}{ccccc}
\hline $\begin{array}{c}\text { Tree } \\
\text { density }\end{array}$ & $\begin{array}{c}\text { Shrub } \\
\text { density }\end{array}$ & $\begin{array}{c}\text { Herbaceous } \\
\text { vegetation }\end{array}$ & $\begin{array}{c}\text { Pellet } \\
\text { occurrence }\end{array}$ & $\begin{array}{c}\text { Number } \\
\text { of plots }\end{array}$ \\
\hline $0-59$ & 53 & 370 & 77 & 64 \\
$60-109$ & 85 & 270 & 91 & 59 \\
$110-159$ & 126 & 250 & 86 & 49 \\
$160-209$ & 124 & 210 & 81 & 20 \\
$210-259$ & 73 & 150 & 81 & 13 \\
\hline
\end{tabular}

of five randomized treatments in each of two blocks. Each treatment plot contained $300-500$ acres. In one treatment, trees were uprooted, piled, and burned. In another treatment, trees were uprooted but left where they fell. Retention of trees on steep slopes and northerly exposures constituted a third treatment. On a fourth area, trees were thinned to a density of 100 trees/ acre by felling with a chain saw. The fifth area was left undisturbed.

In 1968, a supplemental study was made of cottontail use of treatment areas. Accumulated cottontail rabbit pellets were counted on randomly selected sample points on belts of $1 / 400$ acre within the middle of each treatment area. Such measurements permitted quantitative comparisons between relative rabbit abundance, as measured by pellet counts, and characteristics and condition of the surrounding vegetation.

\section{Use of Undisturbed Areas}

Use of natural areas by cottontails was extensively surveyed on 9,000 acres of undisturbed pinyonjuniper in 1966. Evidence of rabbit use was found on $83 \%$ of the area. Within use areas, however, certain combinations of trees, shrubs, and herbaceous plants were preferred.

Evidence of cottontails was greatest (91\% of plots with pellets) where per acre amounts of vegetation averaged 85 trees, 85 shrubs, and $270 \mathrm{lb}$. of perennial grass (Table 1). Pellet occurrence at this tree density differed significantly $(0.05$ level) from that at higher and lower densities of shrubs and trees. This relation suggests that woody plants can be too few or too dense for best cottontail habitat conditions.

To separate the effect of shrubs and overstory trees upon cottontail presence, pellet densities were measured on areas with and without trees. An area of 300 acres near optimum for cottontail presence (Fig. 1) averaging 86 shrubs/acre and 57 trees/acre had a pellet density of 2.8 per square foot. An adjacent of shrubs but without trees, had a density of 3.1 pellets per square foot. This comparison suggests that if sufficient shrubs are present, the habitat will be occupied by cottontails whether living trees are present or not.

Cottontail use is strongly related to shrub density. With an increase from 53 to 85 shrubs per acre, cottontail use increases; between 85 area of comparable size and density and approximately 125 shrubs per acre use by cottontails decreases (Table 1).

Overstory trees can affect cottontail use by suppressing shrubs. Tree density above 160 per acre suppresses shrub abundance. If shrubs are reduced by tree competition below optimum habitat conditions of about 85 shrubs per acre, cottontail use is depressed.

Within the range of 150 to 370 pounds per acre production of herbaceous vegetation does not seem to affect cottontail use.

\section{Use of Modified Areas}

Modifications of cottontail habitat by different methods of tree removal resulted in differences in cottontail use. Pellet densities were significantly lower (0.05 level) from the control plot where all trees were uprooted, piled, and burned (Table 2). Pellet densities were significantly higher than the control where trees were uprooted but left intact. The thinning treatment did not differ significantly from the control area. Since the treatment areas were comparable in density of shrubs (50-59 per acre) the differences in cottontail use suggest that abundance of down, dead trees influenced habitat conditions.

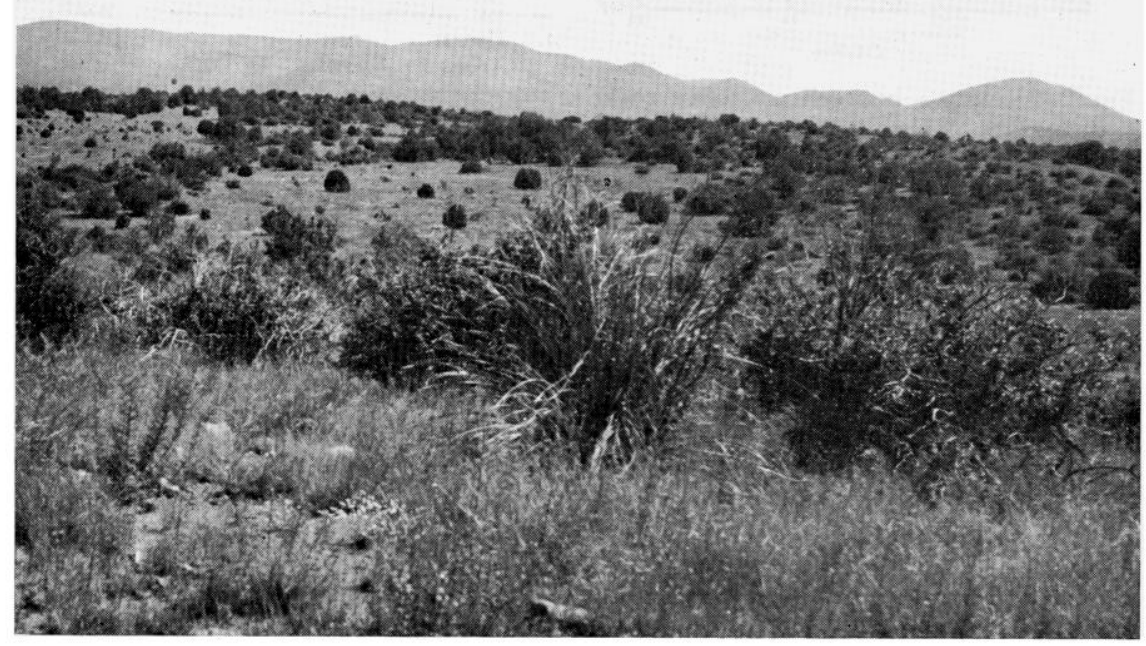

FIG. 1. Ideal desert cottontail habitat on the Ft. Bayard Experimental Forest; shrubs average about 85 per acre and perennial grass is $270 \mathrm{lb}$./acre. 
Table 2. Relation of cottontail pellet densities (no./ft ${ }^{2}$ ) to shrubs and down trees as affected by treatment (after Kundaeli, 1969).

\begin{tabular}{lcccc}
\hline \hline & $\begin{array}{c}\text { Cotton- } \\
\text { tail }\end{array}$ & \multicolumn{3}{c}{ Cover complex (no./acre) } \\
\cline { 3 - 5 } Treatets & Shrubs & $\begin{array}{c}\text { Down } \\
\text { Trecs }\end{array}$ & Total \\
\hline Uprooting all trees & 3.2 & 59 & 31 & 90 \\
Thinning to 100 trees/acre & 2.7 & 58 & 14 & 72 \\
No treatment & 2.4 & 57 & 4 & 61 \\
Uprooting, piling and burning & 1.0 & 50 & 6 & 56 \\
\hline
\end{tabular}

To investigate further the effect of down trees upon cottontail use, various density combinations of shrubs and down trees were related to presence of rabbits as measured by pellet densities. Down, dead trees were assumed to be equivalent to shrubs in their habitat contribution.

Cottontail pellet density increased until cover density of down

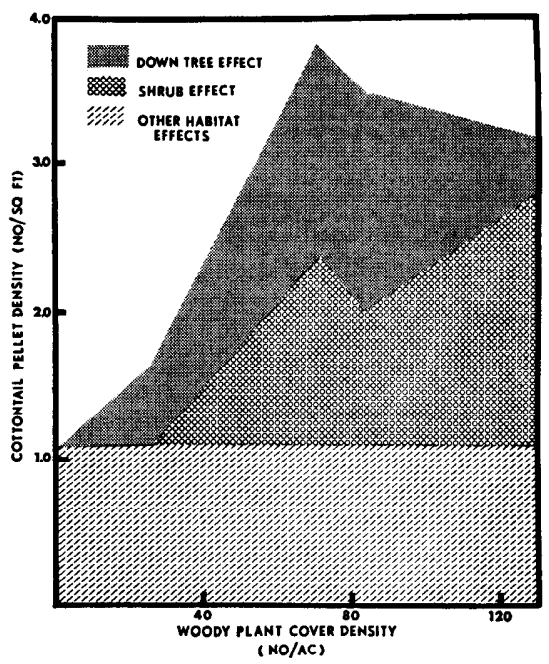

Fic. 2. Relation between collective cover density of down, dead trees and living shrubs, and density of desert cottontail pellets on Ft. Bayard treatment areas in 1968. trees plus shrubs reached 70 per acre; at greater densities of cover, pellet density decreased, but remained comparatively high at the highest density of cover measured$130+$ per acre (Fig. 2).

Further evidence of the desired level of down trees and live shrubs for best cottontail habitat is provided by presence and absence data for cottontail pellets (Table 3). The combined cover of 65 shrubs plus 20 down trees per acre seemed to provide adequate habitat conditions. The difference in percent of plots with pellets is significant (0.05 level).

\section{Conclusions}

In pinyon-juniper woodland, as represented by the Ft. Bayard area,

Table 3. Occurrence (\%) of cottontail pellets in relation to density (no./acre) of down trees and shrubs.

\begin{tabular}{cccc}
\hline \hline & Densities & & $\begin{array}{c}\text { Plots } \\
\text { with } \\
\text { pellets } \\
(\%)\end{array}$ \\
\hline $\begin{array}{c}\text { Down } \\
\text { trees }\end{array}$ & Shrubs & Total & $\begin{array}{c}\text { (\%) } \\
0\end{array}$ \\
23 & 23 & 61 \\
20 & 65 & 85 & 91 \\
52 & 90 & 142 & 91 \\
\hline
\end{tabular}

shrubs furnish the primary cover for cottontails. About 85 shrubs/ acre furnish ideal habitat conditions. Living trees influence habitat conditions only indirectly by suppressing shrubs when tree numbers exceed 160 per acre. However, down trees can serve in lieu of shrubs as cover. From 70 to 90 units of down trees and/or living shrubs seem to provide best habitat conditions.

Uprooting, piling, and burning of all pinyon-juniper trees depressed cottontail rabbit use. Where there are less than 85 shrubs/acre, however, pinyon-juniper control can cnhancc habitat conditions for cottontails, if sufficient down trees are retained to total 70-90 per acre in combination with living shrubs. Where density of living shrubs exceeds 70-90 per acre, habitat will be improved little by leaving down trees.

\section{Literature Cited}

Davis, W. C. 1962. Values of hunting and fishing in Arizona 1960. Univ. Ariz. Bur. Bus. \& Publ. Res. Spec. Study 21. $61 \mathrm{p}$.

Forest Service. 1958. Timber resources for America's future. Forest Service, U. S. Dep. Agr. Forest Res. Rep. 14.

Kundaeli, J. N. 1969. Cottontail rabbit (Sylvilagus audubonii cedrophilus Nelson) response to pinyonjuniper removal. MS. Thesis, Colo. State Univ. 57 p.

Sмiтh, R. H. 1962. Cottontail rabbit survey and hunt information. Ariz. Game \& Fish Dep. W53R12/WP3J1, 2, 3, \& 4. 12 p.

Wilm, H. G., D. F. Costello, ANd G. E. KLIPPLE. 1944. Estimating forage yield by the double sampling method. J. Amer. Soc. Agron. 36:194-203.

The Trail Boss portrays a man, a man willing to accept responsibility, and a man capable of delivering the goods in the face of adversity. The dedication of The Trail Boss to the herd makes it a fitting symbol of the range manager's dedication to animals, land, and people. Both The Boss and today's range manager are more than just cowboys. (Harold F. Heady. J. Range Manage. 20:283) 